\title{
Review
}

\section{Ribosomal Hibernation-Associated Factors in Escherichia coli}

\author{
Yasushi Maki and Hideji Yoshida *(D) \\ Department of Physics, Osaka Medical and Pharmaceutical University, Takatsuki 569-8686, Japan; \\ yasushi.maki@ompu.ac.jp \\ * Correspondence: hideji.yoshida@ompu.ac.jp; Tel.: +81-72-684-7023
}

check for updates

Citation: Maki, Y.; Yoshida, $\mathrm{H}$. Ribosomal Hibernation-Associated Factors in Escherichia coli.

Microorganisms 2022, 10, 33. https:// doi.org/10.3390/microorganisms 10010033

Academic Editor: José Marques Andrade

Received: 1 November 2021

Accepted: 21 December 2021

Published: 24 December 2021

Publisher's Note: MDPI stays neutral with regard to jurisdictional claims in published maps and institutional affiliations.

Copyright: () 2021 by the authors Licensee MDPI, Basel, Switzerland. This article is an open access article distributed under the terms and conditions of the Creative Commons Attribution (CC BY) license (https:// creativecommons.org/licenses/by/ $4.0 /)$.

\begin{abstract}
Bacteria convert active 705 ribosomes to inactive 1005 ribosomes to survive under various stress conditions. This state, in which the ribosome loses its translational activity, is known as ribosomal hibernation. In gammaproteobacteria such as Escherichia coli, ribosome modulation factor and hibernation-promoting factor are involved in forming $100 \mathrm{~S}$ ribosomes. The expression of ribosome modulation factor is regulated by (p)ppGpp (which is induced by amino acid starvation), cAMP-CRP (which is stimulated by reduced metabolic energy), and transcription factors involved in biofilm formation. This indicates that the formation of $100 \mathrm{~S}$ ribosomes is an important strategy for bacterial survival under various stress conditions. In recent years, the structures of $100 \mathrm{~S}$ ribosomes from various bacteria have been reported, enhancing our understanding of the $100 \mathrm{~S}$ ribosome. Here, we present previous findings on the $100 \mathrm{~S}$ ribosome and related proteins and describe the stress-response pathways involved in ribosomal hibernation.
\end{abstract}

Keywords: $100 \mathrm{~S}$ ribosome; ribosome modulation factor; hibernation-promoting factor; ribosomal hibernation; stress response

\section{Introduction}

Bacteria have developed sophisticated adaptive systems to survive during various environmental changes, including nutrient starvation, temperature shock, osmolarity changes, and rapid $\mathrm{pH}$ changes. These systems include inhibition of cell growth, reduction of cell volume, changes in cell shape, compression of nucleoids, changes in the cell wall composition, and changes in cytoplasmic components [1]. These environmental adaptations may result in the formation of biofilms encased in extracellular polymers [2] or the conversion of bacteria into persister cells with reduced vitality [3], making them resistant to antibiotics and responsible for chronic infections [4-7]. To further combat these stress conditions, bacteria utilize a system to dimerize and inactivate ribosomes [8]. In some gammaproteobacteria, such as Escherichia coli and Vibrio cholerae, two ribosomal protein factors, ribosome modulation factor (RMF) and hibernation-promoting factor (HPF), bind to the $70 S$ ribosome to produce its dimeric form, the $100 \mathrm{~S}$ ribosome. In most other bacteria, including Staphylococcus aureus, Lactobacillus paracasei, and Thermus thermophilus, the 100S ribosome is formed through binding of a long-form of HPF to the 70S ribosome [9-11]. A ribosomal hibernation model has been proposed in which the $100 \mathrm{~S}$ ribosome loses its translational activity to reduce cellular energy consumption and functions as a reservoir for protecting ribosomes from degradation by RNases [12-15]. Recently, high-resolution structures of 1005 ribosomes from various bacteria have been reported, improving the understanding of ribosome hibernation [16-20].

In this review, we describe previous findings on the $100 \mathrm{~S}$ ribosome and related protein factors in E. coli, as shown in Table 1. We attempted to integrate the hibernation stage into the ribosome cycle and discuss the elaborate stress response pathway involved in bacterial translational control. 
Table 1. Factors related to ribosome hibernation in Escherichia coli.

\begin{tabular}{cccc}
\hline Name & Mr & Gene Position & $\begin{array}{c}\text { Main Function Related to 100S } \\
\text { Ribosomes }\end{array}$ \\
\hline RMF & Factors directly involved in 100S ribosome formation \\
\hline HPF & $10.5 \mathrm{k}$ & $1016137-1016304$ & Dimerizing ribosomes \\
\hline & Major factors indirectly involved in 100S ribosome formation \\
\hline RaiA & $12.8 \mathrm{k}$ & $2735810-2736151$ & Inhibiting ribosome dimerization \\
\hline RelA & $83.9 \mathrm{k}$ & $2910073-2912307$ & Synthesis of (p)ppGpp \\
\hline YqjD & $11.1 \mathrm{k}$ & $3248031-3248336$ & Localizing ribosomes to membrane \\
\hline
\end{tabular}

\section{100S Ribosome}

Various types of ribosomal dimers have been observed using negative-staining electron microscopy since the 1970s [21,22]. However, ribosomal dimers are not always observable by electron microscopy. Some of these complexes were thought to be linked by ribosomebound mRNAs, whereas others were considered artificial because studies using sucrose density gradient centrifugation showed that ribosomes dimerized in the presence of excess divalent cations in solution. In the 1980s, Wada et al. established an experimental method for stably obtaining ribosomal dimers [23] by avoiding the washing of E. coli cells harvested during the stationary growth phase with fresh buffer. The stable ribosomal dimer, whose sedimentation coefficient was 100S, was analyzed using sucrose density gradient centrifugation and named the $100 \mathrm{~S}$ ribosome. Subsequently, the protein RMF was found to bind to this ribosome, and it was confirmed that adding RMF to the ribosome in vitro caused dimerization (Figure 1) [12,23]. The addition of RMF to ribosomes in vitro resulted in a marked decrease in translational activity, indicating that the $100 \mathrm{~S}$ ribosome is inactive [12].

$100 \mathrm{~S}$ ribosome formation is thought to inhibit the synthesis of proteins that consume large amounts of energy under conditions unfavorable for bacterial growth [8,24]. According to the results of sucrose density gradient centrifugation, around $40 \%$ of all ribosomes are converted to $100 \mathrm{~S}$ ribosomes during the stationary growth phase [23]. However, this measured value is uncertain because the $100 \mathrm{~S}$ ribosome of $E$. coli easily dissociates into $70 \mathrm{~S}$ ribosomes at low ribosomal concentrations [25]. Cryo-electron microscopy tomography in situ revealed that $20-25 \%$ of ribosomes were in the $100 \mathrm{~S}$ form; however, the culture conditions were not optimized to observe large numbers of these ribosomes [26]. In contrast, stoichiometric analysis of ribosomal binding proteins revealed that RMF binds to up to $80 \%$ or more of ribosomes in E. coli cells [27]. Therefore, most ribosomes are thought to be converted to $100 \mathrm{~S}$ ribosomes in the cell depending on the environment.

In E. coli, ribosomes are degraded by exoribonucleases such as RNase R and RNase II in response to environmental stress [14,15]. However, it has been speculated that the $100 \mathrm{~S}$ ribosome complex protects ribosomes from degradation during osmotic or heat stress $[28,29]$. Dormant cells known as persisters, which are resistant to antimicrobial drugs, contain high levels of $100 \mathrm{~S}$ ribosomes [30]. When cells are removed from stress conditions, inactive $100 \mathrm{~S}$ ribosomes quickly dissociate into active $70 \mathrm{~S}$ ribosomes and protein synthesis resumes [31]. It has been reported that EF-G/RRF or Hflx is involved in the dissociation of $100 \mathrm{~S}$ ribosome in S. aureus [32]. However, the $100 \mathrm{~S}$ ribosome of S. aureus is formed by the long form of HPF and not by RMF [10]. Although EF-G/RRF and Hflx are also present in E. coli, it has not been confirmed whether these protein factors can dissociate the $100 \mathrm{~S}$ ribosome formed by RMF in E. coli. In E. coli, it has been reported that IF3 releases HPF from ribosomes but does not release RMF [33].

These studies suggest that the interconversion system between active 70S ribosomes and inactive $100 \mathrm{~S}$ ribosomes is an important strategy for cells to survive in harsh environments. This stage in the translational cycle, in which the ribosome has lost its activity, 
is named the hibernation stage, and ribosomes in this stage are known as hibernation ribosomes [12].

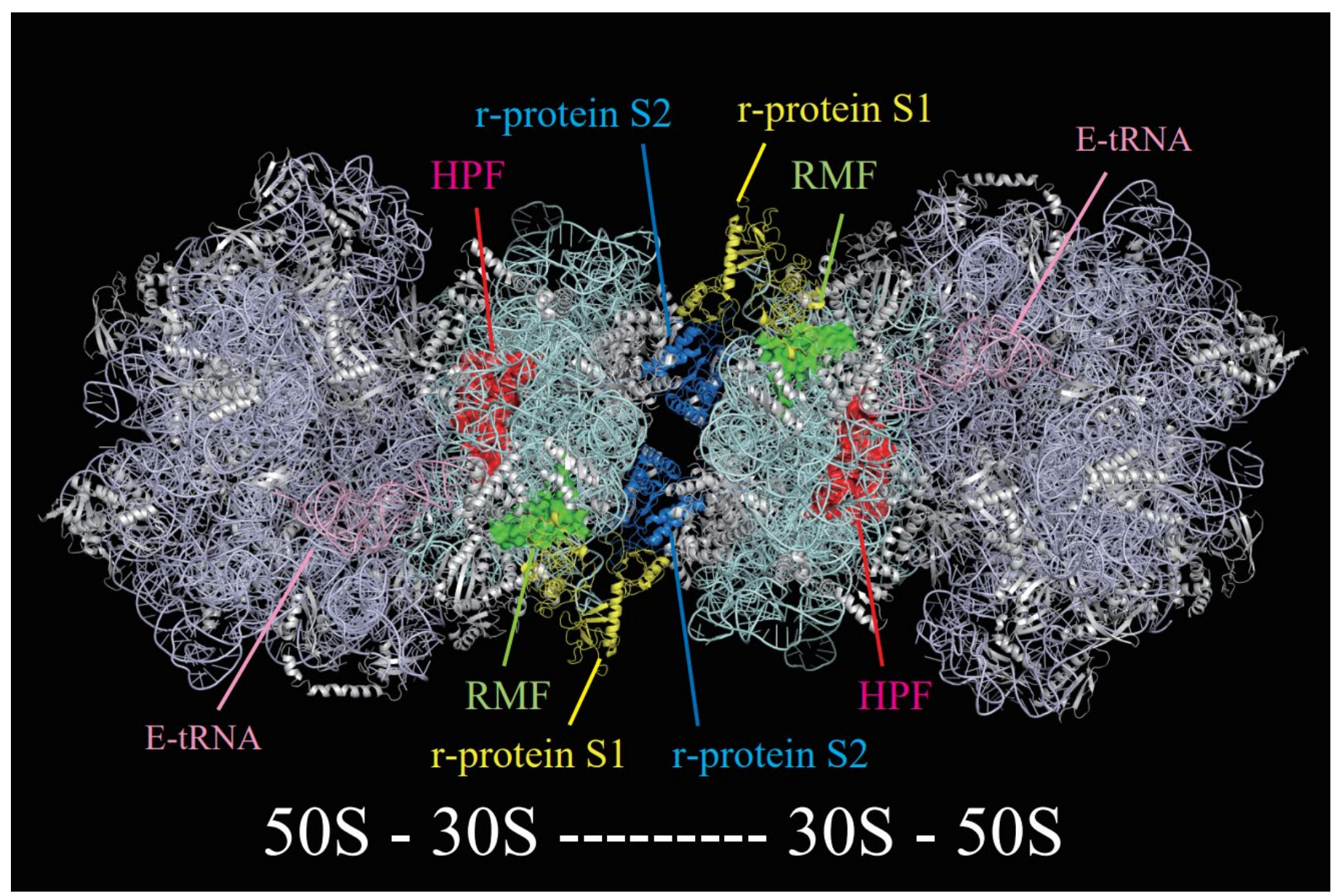

Figure 1. Structure of the $100 \mathrm{~S}$ ribosome in Escherichia coli (PDB ID: 6H58). The 100S ribosome is formed by $30 \mathrm{~S}$ subunits of the two $70 \mathrm{~S}$ ribosomes (50S-30S-30S-50S). RMF, the key factor for ribosome dimerization, is shown in green. HPF, a factor that stabilizes the $100 \mathrm{~S}$ ribosome, is shown in red. Ribosomal proteins S1 and S2, which play important roles in forming the 100S ribosome, are shown in yellow and blue, respectively. The tRNA of the E site bound to the 100S ribosome is shown in pink.

Information on the detailed structure of the $100 \mathrm{~S}$ ribosome in Gram-negative organisms is limited. The structure of the E. coli $100 \mathrm{~S}$ ribosome was revealed using cryo-electron microscopy in 2010 [25]. The $100 \mathrm{~S}$ ribosome is formed by two $70 \mathrm{~S}$ ribosomes that contact each other at the $30 \mathrm{~S}$ subunit (see Figure 1). At the junction of the $30 \mathrm{~S}$ subunits, the ribosomal protein S2 of one subunit fits into the pocket formed by the ribosomal proteins S3, S4, and S5 of the other subunit. This pocket is a pathway for mRNA; therefore, mRNA cannot bind to the $100 \mathrm{~S}$ ribosome if this pocket is blocked by ribosome dimerization. In addition, an extra dense mass has been observed in the $30 \mathrm{~S}$ subunit of the $100 \mathrm{~S}$ ribosome, which was not present in the structure of the previously observed $70 \mathrm{~S}$ ribosome. These structural features of the $100 \mathrm{~S}$ ribosome have also been observed by cryo-electron tomography in situ [26]. Recent structures determined that using cryo-electron microscopy with an improved resolution visualized RMF and HPF on the E. coli 100S ribosome, as shown in Figure 1 [18]. This structure revealed that RMF and HPF mediate 70S dimerization indirectly by stabilizing the ribosomal proteins $\mathrm{S} 1$ and S2, in contrast to those observed in Gram-positive bacteria in which the long-form of HPF directly participates in the dimerization interface $[16,17,19,20,34]$. The structure also indicated the presence of deacylated E-site tRNA and ribosomal protein S1 on the $100 \mathrm{~S}$ ribosome. This ribosomal protein S1 is thought 
to be the extra-dense mass mentioned above. Interestingly, S1 has an inactive structure for translation initiation and contacts the RMF [18].

\section{Preparation of Ribosomal Hibernation}

\subsection{Synthesis of (p)ppGpp on the Ribosome by RelA}

Expression of the $r m f$ gene is known to be controlled by guanosine tetraphosphate and pentaphosphate, collectively known as (p)ppGpp [35]. Depletion of essential nutrients in the environment is among the most serious threats to bacteria. A central component of adaptation to this stress is the stringent response [36] driven by (p)ppGpp, which plays numerous roles in regulating cell growth rates and adapting to the environment [37]. (p)ppGpp regulates transcriptional activity and decreases ribosome biosynthesis for environmental adaptation by interacting with RNA polymerase [38,39]. Intracellular (p)ppGpp levels are regulated by enzymes belonging to the RelA/SpoT homolog family [40]. SpoT is a bifunctional enzyme with strong hydrolytic activity and weak (p)ppGpp synthesis activity ( $<8>$ in Figure 2) [41], whereas RelA is a ribosomal factor with (p)ppGpp synthesis activity (see Table 1) [42]. When the supply of amino acids is limited by nutrient starvation, deacylated tRNA binds to the A site of the $70 \mathrm{~S}$ ribosome $(<6>$ in Figure 2$)$. RelA is activated by binding to deacetylated tRNA-bound 70S ribosomes [43]. Activated RelA transfers the pyrophosphoryl group from ATP to GTP or GDP on the ribosome, synthesizing pppGpp or ppGpp, respectively ( $<7>$ in Figure 2). To understand how RelA synthesizes (p)ppGpp on the deacylated tRNA-bound 70S ribosome, the high-resolution structure of the entire 705 RelA deacyl-tRNA complex was analyzed [44-46]. The structural analysis results showed that the interaction between RelA and the ribosome caused conformational changes in both the $30 \mathrm{~S}$ and $50 \mathrm{~S}$ subunits during (p)ppGpp synthesis. (p)ppGpp is involved in promoting transcription of the $r m f$ gene and strongly affects $100 \mathrm{~S}$ ribosome formation $(<9>$ in Figure 2) [35]. This sequence of events (amino acid starvation $\rightarrow$ synthesis of (p)ppGpp by RelA $\rightarrow$ expression of RMF by (p)ppGpp $\rightarrow$ formation of $100 S$ ribosome by RMF $\rightarrow$ reduction of translational activity by $100 \mathrm{~S}$ ribosome) is congruent with the response to starvation stress.

\subsection{Changes in Ribosomes Because of Growth Phase Transition}

The established ribosome cycle in bacteria consists of initiation, elongation, termination, and recycling stages $(<1>-<4>$ in Figure 2$)$. In the exponential growth phase, when nutrients are sufficient, ribosomes dissociate into subunits in a GTP-dependent reaction involving ribosome recycling factor and elongation factor $G$ after the recycling phase. Thereafter, initiation factor 3 (IF3) binds to the 30S subunit to stabilize the dissociation for the next round of translation $(<5>$ in Figure 2) [47]. However, ribosomes are less likely to be bound by IF3 as the growth phase transitions from the exponential phase to the stationary phase [48]. In contrast, when RMF is added to ribosomes prepared from cells during the exponential phase in vitro, $100 \mathrm{~S}$ ribosomes are less likely to form than when they are prepared from cells during the stationary phase [48]. These results indicate that ribosomes in the exponential and stationary phases are different. Structural analysis showed that the ribosomal protein S1 binds to $100 \mathrm{~S}$ ribosomes, which contacts the RMF [18]. It is known that this ribosomal protein facilitates the unwinding and placement of the start codon of mRNA [49]. Interestingly, the S1 protein on the $100 \mathrm{~S}$ ribosome has an inactive and compact conformation that differs from previously resolved structures. Moreover, the S1 protein has been reported to interact with IF3 [33,50]. The ribosomal protein S1 may play a role in regulating the binding of IF3 to ribosomes and initiating translation or RMF binding to ribosomes and dimerizing them during the transition from the exponential phase to the stationary phase. 


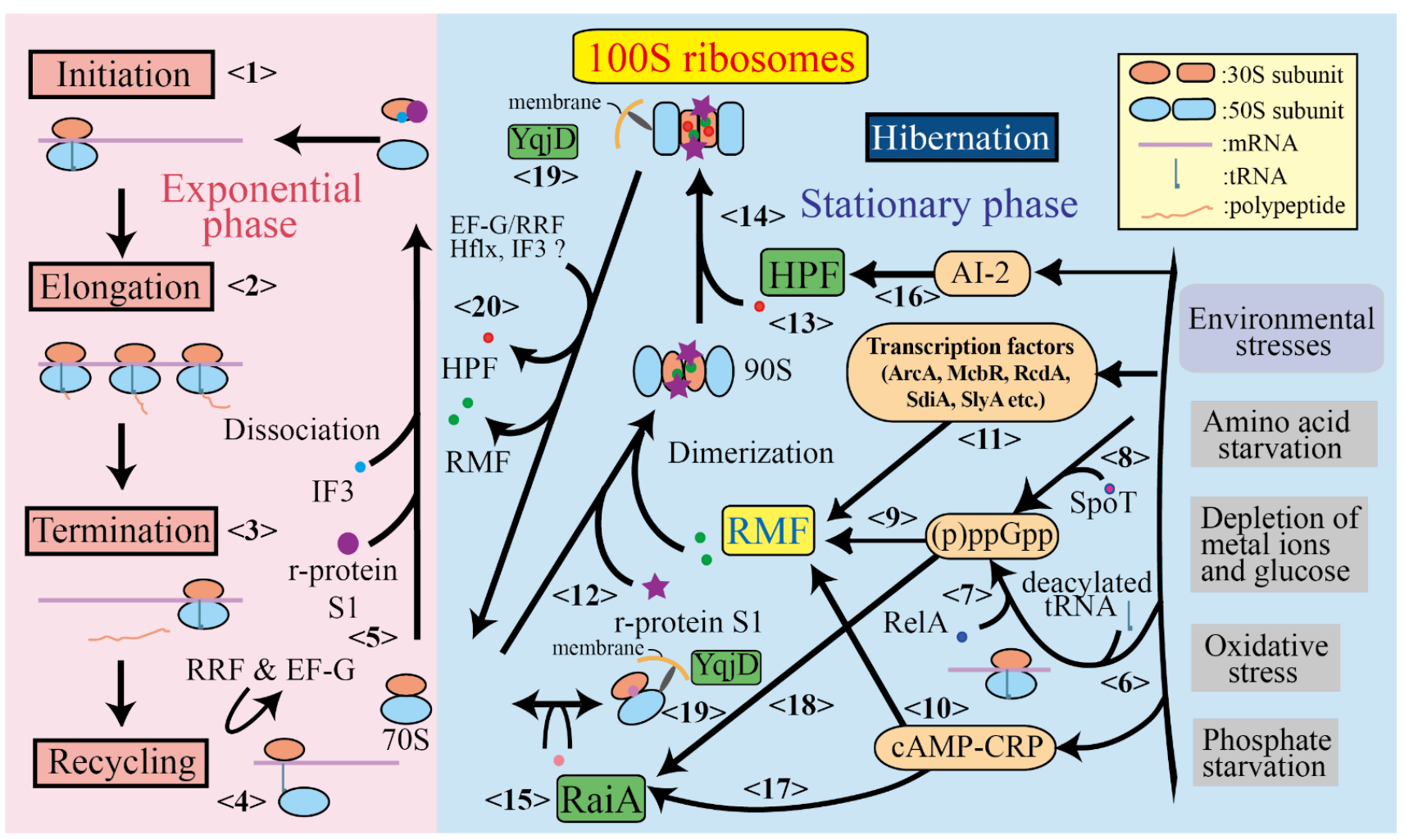

Figure 2. Ribosome cycle including the hibernation stage and expression pathways of factors related to formation of $100 \mathrm{~S}$ ribosome in Escherichia coli. The state of ribosomes in the exponential phase, when cell proliferation is active, and in the stationary phase, when cells are under stress, are shown. The currently known expression pathways of RMF, HPF, and RaiA, factors involved in the formation of the $100 \mathrm{~S}$ ribosome, are depicted.

\section{Factors Affecting 100S Ribosome Formation}

\subsection{Ribosome Modulation Factor}

RMF in E. coli is a small, basic protein consisting of 55 amino acids whose main function is forming the $100 \mathrm{~S}$ ribosome by binding to the $70 \mathrm{~S}$ ribosome (see Table 1$)(<12>$ in Figure 2). The $r m f$ gene is mainly carried by enteropathogenic bacteria belonging to the gammaproteobacteria family, such as E. coli, Vibrio cholerae, and Yersinia pestis [8]. Under culture conditions in a rich medium, RMF was not expressed during the exponential growth phase, but instead, its expression was initiated when the culture entered the stationary phase. The half-life of $r m f$ mRNA transcribed in the stationary phase is approximately $24 \mathrm{~min}$, which is clearly longer than the typical half-life of E. coli mRNA (2-4 min) [31], and its expression level is mainly regulated by ppGpp ( $<9>$ in Figure 2) [35]. Surprisingly, the expression of RMF is not dependent on RpoS (sigma $S$ ), the major alternative transcriptional factor in the stress and stationary phase in E. coli [35]. rmf gene expression is reportedly regulated by numerous elements: cyclic AMP (cAMP) and cAMP receptor protein $(C R P)$ (which are stimulated by a decrease in metabolic energy) $(<10>$ in Figure 2); the transcription factor ArcA (which is involved in redox regulation under anoxic conditions); and the transcription factors McbR, RcdA, SdiA, and SlyA (which are involved in biofilm formation) $(<11>$ in Figure 2) [51,52]. Cells in a biofilm may develop antibiotic resistance by forming $100 \mathrm{~S}$ ribosomes with reduced translational activity [53]. RMF is not only involved in the formation of ribosomal dimers, but also in the resistance of cells to osmotic stress [28], heat stress [29], and acid stress [54] by limiting rRNA damage [14,15]. This indicates that RMF expression is controlled by a number of transcription factors that respond to various stresses [51]. 
The binding sites of RMF on the ribosome have been investigated by protein-protein crosslinking [13], chemical probing [55], and structural analyses [18,56]. The results of these structural analyses indicated that RMF binds near the anti-Shine-Dalgarno region of the $30 S$ subunit (see Figure 1). The structure of the RMF consists of two helices connected by a linker, as determined in nuclear magnetic resonance analysis (PDB ID: 2jRM), X-ray crystallography (PDB ID: 4V8G), and cryo-electron microscopy (PDB ID: 6H4N). Thirteen amino acids of RMF are completely conserved and functionally important, as replacement of one of these residues with alanine suppressed ribosome dimerization [57]. Examination of the functional sites using mutants of RMF revealed that R3, K5, and R11 in the N-terminal domain contribute significantly to ribosome binding. Analysis of the $100 \mathrm{~S}$ ribosome by cryo-electron microscopy showed that R3 and K5 interact with helix 28 of 16S rRNA [18]. In addition, G23 and R45 are important for ribosome dimerization because although RMFs with mutations in these amino acids bind to ribosomes, they cannot form dimers [57]. Thus, RMF contains multiple functional sites for ribosome binding and ribosome dimerization.

\subsection{RaiA and HPF}

Protein $\mathrm{Y}$, the gene product of $y$ fiA, was identified as a factor binding to the intersubunit position of the 30S, which stabilizes the $70 S$ monomer of E. coli ribosomes under low $\mathrm{Mg}^{2+}$ conditions in vitro [58]. Subsequently, this protein was found to inhibit cell-free translation of mRNA in cell extracts of E. coli and be induced under cold-shock stress. Thus, protein $\mathrm{Y}$ was renamed as ribosome-associated inhibitor A (RaiA) and its gene name (yfiA) as raiA, as shown in Table 1 [59]. It has also been reported that RaiA reduces translation errors [60].

RaiA and its paralogous protein $\mathrm{YhbH}$ were found to be associated with hibernating ribosomes in the stationary phase of $E$. coli cells and were released from translating ribosomes soon after starved cells were transferred into a fresh medium. This indicates that these proteins are involved in the storage form of ribosomes in the stationary phase, at least in E. coli, as is the case with RMF [61]. YhbH appeared to promote the formation of $100 S$ ribosomes by converting the immature $90 \mathrm{~S}$ dimer containing RMF; hence, the protein and its gene name were renamed as HPF and $h p f$, respectively, as shown in Table $1(<14>$ in Figure 2) [62]. Although both RaiA and HPF are encoded in the E. coli genome and are highly homologous to each other, HPF binds to 1005 ribosomes with RMF in contrast to RaiA binding to the $70 S$ monomer in the ribosomal fraction $(<15>$ in Figure 2) [61].

Crystallographic and chemical probing analyses revealed that RaiA blocks the peptidyltRNA site (P site) and aminoacyl-tRNA site (A site) of the ribosome and inhibits translation initiation [63]. It was suggested that the HPF binding site overlaps with RaiA because of the high identity of these sequences and their similar structures in solution [64]; nevertheless, HPF promotes $100 S$ formation with RMF, in contrast to RaiA, which prevents dimer formation [62]. The 3D structure of HPF and YfiA on the ribosome showed that these proteins are bound in the channel between the head and body of the 30S subunit where tRNAs and mRNA bind during protein synthesis [56]. It was also suggested that RaiA inhibits 100S formation using its C-terminal short tail, which blocks binding of RMF and prevents RMF-induced dimer formation. Recently, a high-resolution structure of hibernating $100 \mathrm{~S}$ ribosomes from E. coli was reported with well-resolved electron densities for HPF and RMF, revealing a direct interaction of HPF with E-site tRNA, as shown in Figure 1 [18].

Some information on the expression and regulatory mechanisms of the genes of RaiA and HPF in E. coli is known. Expression of both proteins is induced under starved conditions [61], including nitrogen starvation [65]. It has also been reported that the mRNA abundance of $h p f$ is increased by the signal of autoinducer $2(<16>$ in Figure 2) [66]. RaiA was induced under cold-shock treatment [59] and downregulated by FNR, a global regulator of anaerobic metabolism [67]. RaiA and RMF expression is induced by cAMP in response to glucose starvation $(<17>,<10>$ in Figure 2) [51] and by starvation alarmone (p)ppGpp (<18>, <9> in Figure 2) [68]. 
Recently, some results concerning functions of these proteins and storage ribosomes have been reported in several bacterial species. The HPF- or RaiA-bound storage ribosomes of E. coli exhibit resistance to unfolded protein-mediated subunit dissociation and subsequent degradation by cellular ribonucleases, with the intrinsic chaperon activity retained to assist in protein folding [69]. The absence of HPF results in the loss of some proteins from the ribosome during incubation in the stationary phase [70,71]; furthermore, HPF protects ribosomes against degradation in the absence of mRNA by blocking the attack of ribonuclease [72-74]. Although these results include cases of specific species except for gammaproteobacteria, the inter-subunit proteins of non-active ribosomes may typically protect the machinery from degradation under stress conditions.

\section{3. $Y q j D$}

YqjD, whose physiological function was unknown, has been reported to be involved in biofilm formation [75]. This protein is not expressed when rpoS is deleted, indicating that its expression is regulated by the sigma factor RpoS, which is responsible for the transcription of stationary-phase specific genes. YqjD is a membrane-binding protein with a transmembrane helix in the C-terminal region and associates with $70 \mathrm{~S}$ and 100S ribosomes at the N-terminal region (see Table 1) [27]. Therefore, it was concluded that YqjD anchors some ribosomes to the membrane during the stationary phase $(<19>$ in Figure 2). yqjD has been found only in closely related species of E. coli, such as Salmonella typhimuriuma and Shigella flexneri. Escherichia coli possesses two paralogous proteins of YqjD, ElaB, and YgaM. These paralogous proteins have transmembrane helix and ribosome binding activity, which are expressed during the stationary phase as observed for YqjD [27]. One cell has three paralogous proteins, YqjD, ElaB, and YgaM, which may be an important strategy for localizing part of the stationary-phase ribosomes to the membrane.

\section{Conclusions}

The ribosome cycle in bacteria consists of initiation, elongation, termination, and recycling stages, as shown in Figure 2. During the exponential growth phase, the ribosome progresses step-by-step in this cycle $(<1>\rightarrow\langle 2\rangle \rightarrow\langle 3\rangle \rightarrow\langle 4\rangle \rightarrow\langle 5\rangle \rightarrow\langle 1\rangle$ in Figure 2), during which proteins are synthesized. However, the protein synthesis activity in bacteria is inhibited under stressful conditions, such as amino acid starvation. Upon amino acid starvation, the number of deacylated tRNAs initially increases; these tRNAs bind to the A site of the ribosome ( $<6>$ in Figure 2). Once bound, RelA binds to the ribosome and initiates the synthesis of (p)ppGpp ( $<7>$ in Figure 2). Under stress conditions, such as fatty acid starvation, carbon source starvation, phosphate starvation, and hyperosmotic shock, SpoT synthesizes (p)ppGpp ( $<8>$ in Figure 2). Transcription of the $r m f$ gene is mainly induced by (p)ppGpp, which is synthesized by RelA and/or SpoT ( $<9>$ in Figure 2) and regulated by the cAMP-activated global transcriptional regulator CRP $(<10>$ in Figure 2$)$ and the transcription factors involved in biofilm formation McbR, RcdA, SdiA, and SlyA $(<11>$ in Figure 2).

RMF, translated as a protein factor, competes with IF3 for binding to ribosomes that have completed the recycling step (determining whether the ribosome proceeds to $<5>$ or $<12>$ in Figure 2). Prior to this event, as the E. coli culture transitions from the exponential phase to the stationary phase, changes to the ribosome make it less likely to bind to IF3 and more likely to form the $100 \mathrm{~S}$ ribosome mediated by RMF. As ribosomal proteins, S1 and IF3 are bound to the $30 \mathrm{~S}$ subunit in the initiation stage and inactive S1 and RMF are bound to the $100 \mathrm{~S}$ ribosome, S1 protein may be involved in the ribosomal changes described above. The binding of RMF results in the formation of a 70S dimer, which is recognized as a particle with a sedimentation coefficient of $90 \mathrm{~S}$ in sucrose density gradient centrifugation $(<13>$ in Figure 2). The binding of HPF to the unstable 90 S particle transforms it into a mature 100S ribosome ( $<14>$ in Figure 2$)$. HPF expression is known to be controlled by autoinducer 2. In contrast, RaiA, a paralog of HPF, suppresses the formation of the $100 \mathrm{~S}$ ribosome by binding to the $70 \mathrm{~S}$ ribosome $(<15>$ in Figure 2$)$. Its expression is under the 
control of (p)ppGpp ( $<18>$ in Figure 2) and cAMP-CRP ( $<17>$ in Figure 2$)$ as well as RMF. Some of these $70 S$ and $100 S$ ribosomes, which have lost their translation activity during the stationary phase, are localized near the membrane by YqjD $(<19>$ in Figure 2$)$. When the surrounding environment of the cell is improved, the 100S ribosome is immediately converted to an active $70 S$ ribosome by releasing RMF and HPF, and the ribosome cycle resumes $(<20>$ in Figure 2). This ribosomal hibernation system is thought to be suitable for the life cycle of enterobacteria, which are released from starvation and multiply at once when their host eats.

The genes for these ribosomal hibernation factors are scattered throughout the E. coli genome (see Table 1) and use different expression pathways (see Figure 2). The expression levels of these proteins may be regulated according to the type of stress. The formation of $100 \mathrm{~S}$ ribosomes is a key strategy for bacterial survival under various stress conditions, which protects bacteria in the presence of antibiotics. Therefore, determining the expression mechanism of protein factors, such as RMF and HPF, which contribute to the formation of $100 \mathrm{~S}$ ribosomes, will be useful for considering the effective use of antibiotics.

Author Contributions: H.Y. wrote sections on the 100S ribosome and RMF; Y.M. wrote the section on RaiA and HPF. All authors have read and agreed to the published version of the manuscript.

Funding: This work was supported by The Intramural Program for Collaborative Research Projects supported by the Center for Medical Research and Development, OMPU (2021-35-18): Matching fund subsidy and Grant-in-Aid for Scientific Research (JP20K07489) from MEXT (Ministry of Education, Culture, Sports, Science and Technology).

Institutional Review Board Statement: Not applicable.

Informed Consent Statement: Not applicable.

Data Availability Statement: Not applicable.

Acknowledgments: We are grateful to S. Furuike (Osaka Medical and Pharmaceutical University) for his support.

Conflicts of Interest: The authors declare no conflict of interest.

\section{References}

1. Kolter, R.; Siegele, D.A.; Tormo, A. The stationary phase of the bacterial life cycle. Annu. Rev. Microbiol. 1993, 47, 855-874. [CrossRef] [PubMed]

2. Costerton, J.W.; Stewart, P.S.; Greenberg, E.P. Bacterial biofilms: A common cause of persistent infections. Science 1999, 284, 1318-1322. [CrossRef] [PubMed]

3. Wilmaerts, D.; Windels, E.M.; Verstraeten, N.; Michiels, J. General mechanisms leading to persister formation and awakening. Trends Genet. 2019, 35, 401-411. [CrossRef] [PubMed]

4. Stewart, P.S.; Costerton, J.W. Antibiotic resistance of bacteria in biofilms. Lancet 2001, 358, 135-138. [CrossRef]

5. Verstraeten, N.; Knapen, W.; Fauvart, M.; Michiels, J. A Historical Perspective on Bacterial Persistence. Methods Mol. Biol. 2016, 1333, 3-13. [CrossRef] [PubMed]

6. Issakhanian, L.; Behzadi, P. Antimicrobial agents and urinary tract infections. Curr. Pharm. Des. 2019, 25, 1409-1423. [CrossRef] [PubMed]

7. Behzadi, P.; García-Perdomo, H.A.; Karpiński, T.M.; Issakhanian, L. Metallo-ß-lactamases: A review. Mol. Biol. Rep. 2020, 47, 6281-6294. [CrossRef]

8. Yoshida, H.; Wada, A. The $100 \mathrm{~S}$ ribosome: Ribosomal hibernation induced by stress. WIREs RNA 2014, 5, 723-732. [CrossRef]

9. Ueta, M.; Ohniwa, R.L.; Yoshida, H.; Maki, Y.; Wada, C.; Wada, A. Role of HPF (hibernation promoting factor) in translational activity in Escherichia coli. J. Biochem. 2008, 143, 425-433. [CrossRef]

10. Ueta, M.; Wada, C.; Wada, A. Formation of $100 \mathrm{~S}$ ribosomes in Staphylococcus aureus by the hibernation promoting factor homolog Sa HPF. Genes Cells 2010, 15, 43-58. [CrossRef] [PubMed]

11. Ueta, M.; Wada, C.; Daifuku, T.; Sako, Y.; Bessho, Y.; Kitamura, A.; Ohniwa, R.L.; Morikawa, K.; Yoshida, H.; Kato, T.; et al. Conservation of two distinct types of $100 \mathrm{~S}$ ribosome in bacteria. Genes Cells 2013, 18, 554-574. [CrossRef]

12. Wada, A.; Igarashi, K.; Yoshimura, S.; Aimoto, S.; Ishihama, A. Ribosome modulation factor: Stationary growth phase-specific inhibitor of ribosome functions from Escherichia coli. Biochem. Biophys. Res. Commun. 1995, 214, 410-417. [CrossRef] [PubMed]

13. Yoshida, H.; Maki, Y.; Kato, H.; Fujisawa, H.; Izutsu, K.; Wada, C.; Wada, A. The ribosome modulation factor (RMF) binding site on the 100S ribosome of Escherichia coli. J. Biochem. 2002, 132, 983-989. [CrossRef] 
14. Sulthana, S.; Quesada, E.; Deutscher, M.P. RNase II regulates RNase PH and is essential for cell survival during starvation and stationary phase. RNA 2017, 23, 1456-1464. [CrossRef]

15. Dos Santos, R.F.; Quendera, A.P.; Boavida, S.; Seixas, A.F.; Arraiano, C.M.; Andrade, J.M. Major $3^{\prime}-5^{\prime}$ exoribonucleases in the metabolism of coding and non-coding RNA. Prog. Mol. Biol. Transl. Sci. 2018, 159, 101-155. [CrossRef]

16. Franken, L.E.; Oostergetel, G.T.; Pijning, T.; Puri, P.; Arkhipova, V.; Boekema, E.J.; Poolman, B.; Guskov, A. A General mechanism of ribosome dimerization revealed by single-particle cryo-electron microscopy. Nat. Commun. 2017, 8, 722. [CrossRef] [PubMed]

17. Beckert, B.; Abdelshahid, M.; Schäfer, H.; Steinchen, W.; Arenz, S.; Berninghausen, O.; Beckmann, R.; Bange, G.; Turgay, K.; Wilson, D.N. Structure of the Bacillus Subtilis hibernating $100 \mathrm{~S}$ ribosome reveals the basis for $70 S$ dimerization. EMBO J. 2017, 36, 2061-2072. [CrossRef] [PubMed]

18. Beckert, B.; Turk, M.; Czech, A.; Berninghausen, O.; Beckmann, R.; Ignatova, Z.; Plitzko, J.M.; Wilson, D.N. Structure of a hibernating $100 S$ ribosome reveals an inactive conformation of the ribosomal protein S1. Nat. Microbiol. 2018, 3, 1115-1121. [CrossRef]

19. Matzov, D.; Aibara, S.; Basu, A.; Zimmerman, E.; Bashan, A.; Yap, M.-N.F.; Amunts, A.; Yonath, A.E. The cryo-EM structure of hibernating 100S ribosome dimer from pathogenic Staphylococcus aureus. Nat. Commun. 2017, 8, 723. [CrossRef] [PubMed]

20. Khusainov, I.; Vicens, Q.; Ayupov, R.; Usachev, K.; Myasnikov, A.; Simonetti, A.; Validov, S.; Kieffer, B.; Yusupova, G.; Yusupov, M.; et al. Structures and dynamics of hibernating ribosomes from Staphylococcus aureus mediated by intermolecular interactions of HPF. EMBO J. 2017, 36, 2073-2087. [CrossRef]

21. Lake, J.A. Ribosome structure determined by electron microscopy of Escherichia coli small subunits, large subunits and monomeric ribosomes. J. Mol. Biol. 1976, 105, 131-159. [CrossRef]

22. Lake, J.A. Ribosomal subunit orientations determined in the monomeric ribosome by single and by double-labeling immune electron microscopy. J. Mol. Biol. 1982, 161, 89-106. [CrossRef]

23. Wada, A.; Yamazaki, Y.; Fujita, N.; Ishihama, A. Structure and probable genetic location of a "ribosome modulation factor" associated with $100 \mathrm{~S}$ ribosomes in stationary-phase Escherichia coli cells. Proc. Natl. Aca. Sci. USA 1990, 87, 2657-2661. [CrossRef] [PubMed]

24. Prossliner, T.; Skovbo Winther, K.; Sørensen, M.A.; Gerdes, K. Ribosome hibernation. Annu. Rev. Genet. 2018, 52, 321-348. [CrossRef] [PubMed]

25. Kato, T.; Yoshida, H.; Miyata, T.; Maki, Y.; Wada, A.; Namba, K. Structure of the $100 \mathrm{~S}$ ribosome in the hibernation stage revealed by electron cryomicroscopy. Structure 2010, 18, 719-724. [CrossRef] [PubMed]

26. Ortiz, J.O.; Brandt, F.; Matias, V.R.F.; Sennels, L.; Rappsilber, J.; Scheres, S.H.W.; Eibauer, M.; Hartl, F.U.; Baumeister, W. Structure of hibernating ribosomes studied by cryoelectron tomography in vitro and in situ. J. Cell Biol. 2010, 190, 613-621. [CrossRef] [PubMed]

27. Yoshida, H.; Maki, Y.; Furuike, S.; Sakai, A.; Ueta, M.; Wada, A. YqjD is an inner membrane protein associated with stationaryphase ribosomes in Escherichia coli. J. Bacteriol. 2012, 194, 4178-4183. [CrossRef] [PubMed]

28. Garay-Arroyo, A.; Colmenero-Flores, J.M.; Garciarrubio, A.; Covarrubias, A.A. Highly hydrophilic proteins in prokaryotes and eukaryotes are common during conditions of water deficit. J. Biol. Chem. 2000, 275, 5668-5674. [CrossRef] [PubMed]

29. Niven, G.W. Ribosome modulation factor protects Escherichia coli during heat stress, but this may not be dependent on ribosome dimerisation. Arch. Microbiol. 2004, 182, 60-66. [CrossRef]

30. Song, S.; Wood, T.K. ppGpp ribosome dimerization model for bacterial persister formation and resuscitation. Biochem. Biophys. Res. Commun. 2020, 523, 281-286. [CrossRef]

31. Aiso, T.; Yoshida, H.; Wada, A.; Ohki, R. Modulation of MRNA stability participates in stationary-phase-specific expression of ribosome modulation factor. J. Bacteriol. 2005, 187, 1951-1958. [CrossRef] [PubMed]

32. Basu, A.; Shields, K.E.; Yap, M.-N.F. The hibernating $100 \mathrm{~S}$ complex is a target of ribosome-recycling factor and elongation factor G in Staphylococcus aureus. J. Biol. Chem. 2020, 295, 6053-6063. [CrossRef]

33. Moll, I.; Resch, A.; Bläsi, U. Discrimination of $5^{\prime}$-terminal start codons by translation initiation factor 3 is mediated by ribosomal protein S1. FEBS Lett. 1998, 436, 213-217. [CrossRef]

34. Flygaard, R.K.; Boegholm, N.; Yusupov, M.; Jenner, L.B. Cryo-EM structure of the hibernating Thermus thermophilus 100S ribosome reveals a protein-mediated dimerization mechanism. Nat. Commun. 2018, 9, 4179. [CrossRef] [PubMed]

35. Izutsu, K.; Wada, A.; Wada, C. Expression of ribosome modulation factor (RMF) in Escherichia coli requires ppGpp. Genes Cells 2001, 6, 665-676. [CrossRef] [PubMed]

36. Potrykus, K.; Cashel, M. (p)ppGpp: Still magical? Annu. Rev. Microbiol. 2008, 62, 35-51. [CrossRef] [PubMed]

37. Patacq, C.; Chaudet, N.; Létisse, F. Crucial role of ppGpp in the resilience of Escherichia coli to growth disruption. mSphere 2020, 5 , e01132-20. [CrossRef]

38. Cachel, M.; Gentry, D.R.; Hernandez, V.J.; Vinella, D. Escherichia Coli and Salmonella: Cellular and Molecular Biology, 2nd ed.; Neidhardt, F.C., Ed.; ASM Press: Washington, DC, USA, 1996; ISBN 978-1-55581-084-9.

39. Lemke, J.J.; Sanchez-Vazquez, P.; Burgos, H.L.; Hedberg, G.; Ross, W.; Gourse, R.L. Direct regulation of Escherichia coli ribosomal protein promoters by the transcription factors ppGpp and DksA. Proc. Natl. Acad. Sci. USA 2011, 108, 5712-5717. [CrossRef] [PubMed]

40. Atkinson, G.C.; Tenson, T.; Hauryliuk, V. The RelA/SpoT homolog (RSH) superfamily: Distribution and functional evolution of ppGpp synthetases and hydrolases across the tree of life. PLoS ONE 2011, 6, e23479. [CrossRef] [PubMed] 
41. Xiao, H.; Kalman, M.; Ikehara, K.; Zemel, S.; Glaser, G.; Cashel, M. Residual guanosine 3',5'-bispyrophosphate synthetic activity of RelA null mutants can be eliminated by SpoT null mutations. J. Biol. Chem. 1991, 266, 5980-5990. [CrossRef]

42. Shyp, V.; Tankov, S.; Ermakov, A.; Kudrin, P.; English, B.P.; Ehrenberg, M.; Tenson, T.; Elf, J.; Hauryliuk, V. Positive allosteric feedback regulation of the stringent response enzyme RelA by its product. EMBO Rep. 2012, 13, 835-839. [CrossRef] [PubMed]

43. Wendrich, T.M.; Blaha, G.; Wilson, D.N.; Marahiel, M.A.; Nierhaus, K.H. Dissection of the mechanism for the stringent factor RelA. Mol. Cell 2002, 10, 779-788. [CrossRef]

44. Arenz, S.; Abdelshahid, M.; Sohmen, D.; Payoe, R.; Starosta, A.L.; Berninghausen, O.; Hauryliuk, V.; Beckmann, R.; Wilson, D.N The stringent factor RelA adopts an open conformation on the ribosome to stimulate ppGpp synthesis. Nucleic Acids Res. 2016, 44, 6471-6481. [CrossRef] [PubMed]

45. Brown, A.; Fernández, I.S.; Gordiyenko, Y.; Ramakrishnan, V. Ribosome-dependent activation of stringent control. Nature 2016, 534, 277-280. [CrossRef] [PubMed]

46. Loveland, A.B.; Bah, E.; Madireddy, R.; Zhang, Y.; Brilot, A.F.; Grigorieff, N.; Korostelev, A.A. Ribosome•RelA structures reveal the mechanism of stringent response activation. eLife 2016, 5, e17029. [CrossRef] [PubMed]

47. Karimi, R.; Pavlov, M.Y.; Buckingham, R.H.; Ehrenberg, M. Novel roles for classical factors at the interface between translation termination and initiation. Mol. Cell 1999, 3, 601-609. [CrossRef]

48. Yoshida, H.; Ueta, M.; Maki, Y.; Sakai, A.; Wada, A. Activities of Escherichia coli ribosomes in IF3 and RMF change to prepare 100S ribosome formation on entering the stationary growth phase. Genes Cells 2009, 14, 271-280. [CrossRef]

49. Qu, X.; Lancaster, L.; Noller, H.F.; Bustamante, C.; Tinoco, I. Ribosomal protein S1 unwinds double-stranded RNA in multiple steps. Proc. Natl. Acad. Sci. USA 2012, 109, 14458-14463. [CrossRef] [PubMed]

50. Laughrea, M.; Tam, J. Interaction of ribosomal protein S1 and initiation factor IF3 with the 3' major domain and the decoding site of the 30 S subunit of Escherichia coli. Biochemistry 1991, 30, 11412-11420. [CrossRef]

51. Shimada, T.; Yoshida, H.; Ishihama, A. Involvement of cyclic AMP receptor protein in regulation of the $r m f$ gene encoding the ribosome modulation factor in Escherichia coli. J. Bacteriol. 2013, 195, 2212-2219. [CrossRef] [PubMed]

52. Yoshida, H.; Shimada, T.; Ishihama, A. Coordinated hibernation of transcriptional and translational apparatus during growth transition of Escherichia coli to stationary phase. mSystems 2018, 3, e00057-18. [CrossRef] [PubMed]

53. Boehm, A.; Steiner, S.; Zaehringer, F.; Casanova, A.; Hamburger, F.; Ritz, D.; Keck, W.; Ackermann, M.; Schirmer, T.; Jenal, U. Second messenger signalling governs Escherichia coli biofilm induction upon ribosomal stress. Mol. Microbiol. 2009, 72, 1500-1516. [CrossRef] [PubMed]

54. El-Sharoud, W.M.; Niven, G.W. The activity of ribosome modulation factor during growth of Escherichia coli under acidic conditions. Arch. Microbiol. 2005, 184, 18-24. [CrossRef] [PubMed]

55. Yoshida, H.; Yamamoto, H.; Uchiumi, T.; Wada, A. RMF inactivates ribosomes by covering the peptidyl transferase centre and entrance of peptide exit tunnel. Genes Cells 2004, 9, 271-278. [CrossRef] [PubMed]

56. Polikanov, Y.S.; Blaha, G.M.; Steitz, T.A. How hibernation factors RMF, HPF, and YfiA turn off protein synthesis. Science 2012, 336, 915-918. [CrossRef] [PubMed]

57. Yoshida, H.; Nakayama, H.; Maki, Y.; Ueta, M.; Wada, C.; Wada, A. Functional sites of ribosome modulation factor (RMF) involved in the formation of $100 \mathrm{~S}$ ribosome. Front. Mol. Biosci. 2021, 8, 661691. [CrossRef] [PubMed]

58. Agafonov, D.E.; Kolb, V.A.; Nazimov, I.V.; Spirin, A.S. A protein residing at the subunit interface of the bacterial ribosome. Proc. Natl. Acad. Sci. USA 1999, 96, 12345-12349. [CrossRef]

59. Agafonov, D.E.; Kolb, V.A.; Spirin, A.S. Ribosome-associated protein that inhibits translation at the aminoacyl-TRNA binding stage. EMBO Rep. 2001, 2, 399-402. [CrossRef]

60. Agafonov, D.E.; Spirin, A.S. The ribosome-associated inhibitor A reduces translation errors. Biochem. Biophys. Res. Commun. 2004, 320, 354-358. [CrossRef]

61. Maki, Y.; Yoshida, H.; Wada, A. Two proteins, YfiA and $\mathrm{YhbH}$, associated with resting ribosomes in stationary phase Escherichia coli. Genes Cells 2000, 5, 965-974. [CrossRef]

62. Ueta, M.; Yoshida, H.; Wada, C.; Baba, T.; Mori, H.; Wada, A. Ribosome binding proteins YhbH and YfiA have opposite functions during $100 S$ formation in the stationary phase of Escherichia coli. Genes Cells 2005, 10, 1103-1112. [CrossRef]

63. Vila-Sanjurjo, A.; Schuwirth, B.-S.; Hau, C.W.; Cate, J.H.D. Structural basis for the control of translation initiation during stress. Nat. Struct. Mol. Biol. 2004, 11, 1054-1059. [CrossRef]

64. Sato, A.; Watanabe, T.; Maki, Y.; Ueta, M.; Yoshida, H.; Ito, Y.; Wada, A.; Mishima, M. Solution structure of the E. coli ribosome hibernation promoting factor HPF: Implications for the relationship between structure and function. Biochem. Biophys. Res. Commun. 2009, 389, 580-585. [CrossRef] [PubMed]

65. Sanchuki, H.B.S.; Gravina, F.; Rodrigues, T.E.; Gerhardt, E.C.M.; Pedrosa, F.O.; Souza, E.M.; Raittz, R.T.; Valdameri, G.; de Souza, G.A.; Huergo, L.F. Dynamics of the Escherichia coli Proteome in Response to Nitrogen Starvation and Entry into the Stationary Phase. Biochim. Biophys. Acta (BBA) Proteins Proteom. 2017, 1865, 344-352. [CrossRef]

66. DeLisa, M.P.; Wu, C.-F.; Wang, L.; Valdes, J.J.; Bentley, W.E. DNA microarray-based identification of genes controlled by autoinducer 2-stimulated quorum sensing in Escherichia coli. J. Bacteriol. 2001, 183, 5239-5247. [CrossRef] [PubMed]

67. Salmon, K.; Hung, S.; Mekjian, K.; Baldi, P.; Hatfield, G.W.; Gunsalus, R.P. Global gene expression profiling in Escherichia coli K12. The effects of oxygen availability and FNR. J. Biol. Chem. 2003, 278, 29837-29855. [CrossRef] 
68. Durfee, T.; Hansen, A.-M.; Zhi, H.; Blattner, F.R.; Jin, D.J. Transcription profiling of the stringent response in Escherichia coli. J. Bacteriol. 2008, 190, 1084-1096. [CrossRef] [PubMed]

69. Ferdosh, S.; Banerjee, S.; Pathak, B.K.; Sengupta, J.; Barat, C. Hibernating ribosomes exhibit chaperoning activity but can resist unfolded protein-mediated subunit dissociation. FEBS J. 2021, 288, 1305-1324. [CrossRef]

70. Theng, S.; Williamson, K.S.; Franklin, M.J. Role of hibernation promoting factor in ribosomal protein stability during Pseudomonas aeruginosa dormancy. Int. J. Mol. Sci. 2020, 21, 9494. [CrossRef] [PubMed]

71. Feaga, H.A.; Kopylov, M.; Kim, J.K.; Jovanovic, M.; Dworkin, J. Ribosome dimerization protects the small subunit. J. Bacteriol. 2020, 202, e00009-20. [CrossRef] [PubMed]

72. Feaga, H.A.; Dworkin, J. Transcription regulates ribosome hibernation. Mol. Microbiol. 2021, 116, 663-673. [CrossRef] [PubMed]

73. Prossliner, T.; Gerdes, K.; Sørensen, M.A.; Winther, K.S. Hibernation factors directly block ribonucleases from entering the ribosome in response to starvation. Nucleic Acids Res. 2021, 49, 2226-2239. [CrossRef]

74. Lipońska, A.; Yap, M.-N.F. Hibernation-promoting factor sequesters Staphylococcus aureus ribosomes to antagonize RNase R-mediated nucleolytic degradation. mBio 2021, 12, e00334-21. [CrossRef]

75. Yang, X.; Ma, Q.; Wood, T.K. The R1 conjugative plasmid increases Escherichia coli biofilm formation through an envelope stress response. Appl. Environ. Microbiol. 2008, 74, 2690-2699. [CrossRef] [PubMed] 